\title{
Division of the genus Enterococcus into species groups using PCR-based molecular typing methods
}

\author{
Hans-Jürg Monstein, ${ }^{1}$ Mikael Quednau, ${ }^{2}$ Annika Samuelsson, ${ }^{1}$ \\ Siv Ahrné, ${ }^{2}$ Barbro Isaksson ${ }^{1}$ and Jon Jonasson ${ }^{1}$
}

Author for correspondence: Hans-Jürg Monstein. Tel: +461322 24 75. Fax: +4613224596.

1 Division of Clinical Microbiology, Faculty of Health Sciences, University Hospital, S-581 85 Linköping, Sweden

2 Laboratory of Food Hygiene, Department of Food Technology, University of Lund, S-221 00 Lund, Sweden

\begin{abstract}
Broad-range 165 rDNA PCR (BR-PCR) applied to DNA from 32 clinical enterococcal isolates and 12 other enterococci from a clinical reference collection followed by species-specific hybridization analysis identified 25 strains of Enterococcus faecalis and 19 Enterococcus species. Randomly amplified polymorphic DNA (RAPD) analysis using UPGMA clustering on the same material revealed four different clusters at a similarity level of $49 \%$. Based on partial 165 rDNA sequence analysis of variable regions V4 and V9, it was possible to divide the 19 type strains specifying the genus Enterococcus into 12 different 165 rDNA species groups. The type strain distribution then served as a template for the analysis of the other $\mathbf{4 4}$ strains which were assigned to four different species groups (a-d) based on their 165 rDNA motifs. There was good agreement with the RAPD clusters. Species group a was an individual species line containing $\mathbf{2 5}$ strains that were identified as $E$. faecalis. Group b also represented an individual species line of 12 strains identified as $E$. faecium. The remaining seven strains that formed species groups $c$ and $d$ could not be fully identified to species by this analysis. It was concluded that BR-PCR of 165 rDNA followed by partial sequence analysis of the PCR products is a reliable technique for the identification and classification of enterococci. Further division of unresolved species groups should be achievable if regions other than V4 and V9 of 165 rDNA are also analysed.
\end{abstract}

Keywords: Enterococcus, 16S rDNA PCR, enterococcal 16S rDNA sequences, enterococcal RAPD analysis

\section{INTRODUCTION}

Enterococci are opportunistic human pathogens. The two most important species, Enterococcus faecalis and Enterococcus faecium, which are considered part of the normal intestinal flora, are among the leading causes of nosocomial infection and may cause severe infections,

\footnotetext{
Abbreviations: BR-PCR, broad-range PCR; ITS, intergenic spacer; RAPD, randomly amplified polymorphic DNA.

The EMBL accession numbers for the sequences reported in this paper are Y12905-Y12924 for Enterococcus faecalis ATCC 19433', E. faecium ATCC $19434^{\top}$, E. avium ATCC $14025^{\top}$, E. casseliflavus ATCC $25788^{\top}$, E. durans ATCC $19432^{\top}$, E. gallinarum CCUG $18658^{\top}$, E. malodoratus CCUG 30572, E. hirae ATCC $8043^{\top}$, E. mundtii CCUG $18656^{\top}$, E. raffinosus CCUG $29292^{\top}$, E. solitarius CCUG $29293^{\top}$, E. pseudoavium CCUG $33310^{\top}$, E. cecorum CCUG $27299^{\top}, E$. columbae CCUG $27894^{\top}$, E. saccharolyticus ATCC $43076^{\top}$, E. dispar CCUG $33309^{\top}$, E. sulfureus CCUG $33313^{\top}$, E. seriolicida CCUG $33312^{\top}$, E. flavescens CCUG $30567^{\top}$ and Streptococcus pyogenes ATCC $19615^{\top}$, respectively.
}

including endocarditis and septicaemia with high mortality (Moellering, 1995). Recent studies have revealed that more unusual strains such as Enterococcus avium, Enterococcus durans and Enterococcus gallinarum constitute a significant proportion of enterococci isolated from clinical blood samples (Miele et al., 1995; Perlada et al., 1997).

Enterococci are intrinsically resistant to a number of antimicrobial agents, including cephalosporins. Strains resistant to high levels of aminoglycosides, all $\beta$-lactam antibiotics and, more recently, the glycopeptide vancomycin have emerged (Arthur \& Courvalin, 1993; Center for Disease Control and Prevention, 1993; Landman et al., 1993). E. faecium is more frequently found than $E$. faecalis among multi-resistant strains. The resistance genes are transferable to other pathogens, at least under laboratory conditions (Noble et al., 1992; Poyart et al., 1997) and this is a cause for concern. 
Infection control and epidemiological studies require simple means of identification and typing of clinical isolates. No phenotypic criteria are available which unequivocally separate the genus Enterococcus from other Gram-positive, catalase-negative cocci (Devriese et al., 1993). Delineation of the genus was founded on serological studies and 16S rRNA sequences (Schleifer \& Kilpper-Bälz, 1984) which, together with nucleic acid hybridization analysis, characterized enterococci as a genetically distinct but heterogeneous group (Schleifer \& Kilpper-Bälz, 1987). The genus Enterococcus was divided into the faecium, avium and gallinarum groups (reviewed by Facklam \& Sahm, 1995) while E. faecalis forms a distinct lineage (Williams et al., 1991). Division of the genus Enterococcus into new species groups based on PCR amplification of the intergenic spacer (ITS) between the 16S and 23S rRNA genes was suggested recently (Naïmi et al., 1997; Tyrell et al., 1997).

Nineteen species (Devriese et al., 1993; Facklam \& Sahm, 1995) are presently included in the genus Enterococcus, of which E. faecalis and E. faecium comprise about 90 and $5-10 \%$, respectively, of the isolates in a typical clinical setting (Facklam \& Sahm, 1995). Various molecular biological techniques, such as intergenic ribosomal PCR (Naïmi et al., 1997; Tyrell et al., 1997), PCR-based glycopeptide resistance genotyping (DutkaMalen et al., 1995; Miele et al., 1995), randomly amplified polymorphic DNA (RAPD) analysis (Berg et al., 1994; Issack et al., 1996; Power, 1996; Descheemaeker et al., 1997), restriction enzyme analysis (Hall et al., 1992), PFGE (Murray et al., 1990; Goering \& Winters, 1992), ribotyping (Kostman et al., 1995; Woodford et al., 1993) and plasmid profiling (Boyce et al., 1992), have been used to study the intrageneric relationships and also for 'fingerprinting' when studying nosocomial transmission of enterococcal strains.

Broad-range PCR (BR-PCR) amplification (Chen et al., 1989), using conserved universal 16 rDNA PCR amplification primers, is another powerful tool to study phylogenetic relationships between bacteria (Stahl \& Amann, 1991; Relman et al., 1992; Amann et al., 1995). Recently, we reported the use of universal 16S rDNA primers for BR-PCR amplification of selected variable regions V3, V4 and V9 of bacterial 16S rDNA (Monstein et al., 1996; Tiveljung et al., 1995, 1996). Direct sequencing of such BR-PCR products is nearly always highly informative for determining genus affiliation and sometimes species.

The purpose of this investigation was to evaluate the discriminatory power of PCR-based methods, including BR-PCR-hybridization and DNA sequence analysis of $16 S$ rDNA BR-PCR-amplified products, for typing of enterococci in comparison with RAPD analysis.

\section{METHODS}

Enterococcal strains and culture conditions. A reference collection of clinical isolates of enterococci (Malmö reference collection) originally characterized by conventional phenotyping using API 20 strep and RAPD analysis, including enterococcal type strains, was received from A. K. Petersson,
Department of Microbiology, University Hospital, Lund. This comprised a set of 12 strains which were numbered $\mathrm{HJ} 1-\mathrm{HJ}$ 12 (HJ 1, E. raffinosus AKP; HJ 2, E. faecalis V583; HJ 3, E. casseliflauus B77; $\mathrm{HJ} 4$, E. gallinarum B41; $\mathrm{HJ} 5$, E. faecium B36; HJ 6, E. faecalis ATCC $19433^{\mathrm{T}}$; HJ 7, E. faecalis B8; HJ 8, E. faecium B4; HJ 9, E. faecalis ATCC 29212; HJ 10, E. gallinarum B95; HJ 11, E. faecalis B1; HJ 12, E. faecium B5). The enterococcal clinical isolates in this investigation were obtained between January and May 1996 from routine clinical specimens at the University Hospital, Linköping. They were putatively identified as enterococci by Gram staining, colony morphology and a positive bile aesculin reaction, and consecutively labelled HJ 13-HJ 45. E. faecalis ATCC 29212 (HJ 22) and E. faecium ATCC 35607 (HJ 21) were included as blind controls in the study. The 19 enterococcal type strains were obtained from the culture collection at the University of Gothenburg, Sweden. All strains were cultured on blood agar plates or in Brain Heart Infusion (Difco) broth (BHI) overnight at $37^{\circ} \mathrm{C}$ and stored frozen in $20 \%(\mathrm{v} / \mathrm{v})$ glycerol in BHI at $-70^{\circ} \mathrm{C}$.

Bacterial strains of other genera. Helicobacter pylori CCUG $17874^{\mathrm{T}}$, Streptococcus pyogenes ATCC 19615, Lactococcus lactis ATCC $19435^{\mathrm{T}}$, Bordetella pertussis CCUG 30873, Escherichia coli ATCC 25922 and clinical isolates identified as Chlamydia trachomatis, Mobiluncus sp., Listeria monocytogenes, Staphylococcus aureus, Actinomyces sp., Acinetobacter sp. and coagulase-negative Staphylococcus sp. were used in this study. All identifications of clinical isolates were established at the University Hospital, Linköping using routine procedures.

Preparation of crude cell extract for RAPD-PCR. Cells from $1 \mathrm{ml}$ of an overnight culture were collected by centrifugation, washed twice in $1 \mathrm{ml}$ sterile distilled water and finally resuspended in $200 \mu \mathrm{l}$ sterile distilled water. The cells were disintegrated by vigorous shaking with 10 glass beads $(0.2 \mathrm{~mm}$ diam.) in each tube using an Eppendorf mixer 5432 for $45 \mathrm{~min}$ at $4{ }^{\circ} \mathrm{C}$. The disrupted cells were pelleted by centrifugation and $1 \mu$ of the supernatant fluid was used for the RAPD-PCR reaction.

BR-PCR amplification and Southern blot analysis. Bacterial DNA was extracted according to a recently described procedure (Monstein et al., 1996), which was developed for the isolation of DNA from both Gram-positive and -negative bacteria and intended for use in 16S rDNA BR-PCR amplifications, and was quantified spectrophotometrically at $260 / 280 \mathrm{~nm}$.

The universal 16S rDNA PCR primers $p J B-1$ and $p 13 B$, which amplify an approximately $440 \mathrm{bp}$ fragment of the $16 \mathrm{~S}$ rRNA gene between positions 959 and 1397 (located within the second half of the $16 \mathrm{~S}$ rDNA gene), including variable regions V3, V4 and V9 (nomenclature from Gray et al., 1984), were used. BR-PCR amplifications were carried out under conditions described previously (Monstein et al., 1996; Tiveljung et al., 1995, 1996). PCR-amplified $16 \mathrm{~S}$ rDNA products $(8 \mu \mathrm{l})$ were subjected to agarose gel electrophoresis as described by Tiveljung et al. (1995). The products were stained with ethidium bromide and documented photographically. $[\gamma-$ ${ }^{32} \mathrm{P}$ ]ATP $5^{\prime}$-end-labelling of hybridization probes $E$. faecalis V9 (5' TGCATGACCTCGCGGTC $\left.3^{\prime}\right)$, E. faecium V9 $\left(5^{\prime}\right.$ AGCTTAGCCTCGCGACT $3^{\prime}$ ) at positions 1247-1268 and the universal BR-PCR primer pJB-1 ( $5^{\prime}$ ATTCGATGCAACGCGAAGAACCTTACC $3^{\prime}$ ) was performed as described previously using $\left[\gamma^{32} \mathrm{P}\right] \mathrm{ATP}$ (Tiveljung et al., 1995). For Southern blot analysis, PCR products were capillary-transferred onto a Hybond-N membrane (Amersham) and fixed to the membrane by cross-linking in a UV box (Stratagene 1800). 
Hybridization conditions, using $\left[\gamma_{-}{ }^{32} \mathrm{P}\right] \mathrm{ATP} 5^{\prime}$-end-labelled hybridization probes, were as described by Tiveljung $e t$ al. (1995). Subsequently, filters were washed in $1 \times$ SSC $/ 0 \cdot 1 \%$ SDS, followed by $0.5 \times$ SSC $/ 0.1 \%$ SDS and $0.25 \times$ SSC $/ 0.1 \%$ SDS for $3 \times 20 \mathrm{~min}$ in each wash at $50{ }^{\circ} \mathrm{C}(1 \times \mathrm{SSC}=150 \mathrm{mM}$ $\mathrm{NaCl}, 15 \mathrm{mM}$ sodium citrate). After each washing step, membranes were exposed to Amersham MP X-ray films at $-80^{\circ} \mathrm{C}$ using a DuPont intensifier screen for $12-14 \mathrm{~h}$.

Between each hybridization step, the filters were recycled by boiling in sterile water $/ 0.5 \%$ SDS for $2-5 \mathrm{~min}$ and exposed overnight to ensure that the hybridized probe was stripped off prior to a new hybridization step. To ascertain the specificity of the PCR amplification, negative control (PCR mix, without DNA template) and positive control (PCR mix with Escherichia coli DNA template) experiments were included.

RAPD-PCR. RAPD-PCR was carried out in a $50 \mu$ l reaction mix

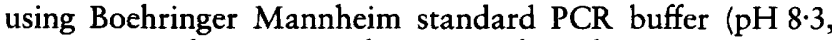
$1.5 \mathrm{mM} \mathrm{MgCl}_{2}$ ), $0.2 \mathrm{mM}$ dNTPs (Perkin-Elmer), $5 \mathrm{mM}$ random primer ( $5^{\prime}$ ACGCGCCCT 3', synthesized by Scandinavian Gene Synthesis, Köping, Sweden) and 2.5 units Taq polymerase (Boehringer Mannheim). The reaction mix was overlaid with mineral oil and the following cycle program was used: $94^{\circ} \mathrm{C}$ for $45 \mathrm{~s}, 30^{\circ} \mathrm{C}$ for $2 \mathrm{~min}$ and $72{ }^{\circ} \mathrm{C}$ for $60 \mathrm{~s}$ for four cycles, followed by $94^{\circ} \mathrm{C}$ for $5 \mathrm{~s}, 36^{\circ} \mathrm{C}$ for $30 \mathrm{~s}$ and $72{ }^{\circ} \mathrm{C}$ for $30 \mathrm{~s}$ for 26 cycles (the extension step was increased by $1 \mathrm{~s}$ for every new cycle). The PCR reaction was terminated at $72{ }^{\circ} \mathrm{C}$ for $10 \mathrm{~min}$ and thereafter cooled to $4^{\circ} \mathrm{C}$.

Gel electrophoresis. PCR products $(20 \mu \mathrm{l})$ were applied to a $1.5 \%(\mathrm{w} / \mathrm{v})$ agarose gel followed by electrophoresis in TB buffer ( $89 \mathrm{mM}$ boric acid, $23 \mathrm{mM} \mathrm{H}_{3} \mathrm{PO}_{4}, 2.5 \mathrm{mM}$ EDTA, $\mathrm{pH} 8.3$ ) at room temperature for about $2.5 \mathrm{~h}$ at $100 \mathrm{~V}$. A DNA molecular mass standard (VI, $0.5 \mu \mathrm{g}$; Boehringer Mannheim) was used. Gels were stained in ethidium bromide for $5 \mathrm{~min}$ and thereafter washed for $10 \mathrm{~min}$. The PCR products were visualized at $302 \mathrm{~nm}$ with a UV transilluminator (UVP) and photographed.

Reading of RAPD patterns, numerical analysis and evaluation of reproducibility. Photographic negatives were scanned into a computer using a flatbed scanner (UMAX) at a resolution of 200 d.p.i. The gel images were then converted to GelCompar format (Applied Maths). Size markers which were included on each gel were used for normalization and all further analysis of the gels was done using GelCompar 4.0. The gel traces were analysed using the Pearson product moment correlation coefficient $(r)$ and the unweighted pair group method with arithmetic means (Romersburg, 1984). The reproducibility test of RAPD analysis was evaluated running all strains in duplicate (separate cell preparations and PCR trials of the same strain) on different gels, followed by UPGMA cluster analysis (Romersburg, 1984).

Partial 16S rDNA sequence analysis of BR-PCR products. PCR products (clinical isolates $\mathrm{HJ} 1-\mathrm{HJ} 44$ and type strains $\mathrm{HJ}$ 46-HJ 64) were subjected to DNA sequence analysis using $5^{\prime}$ fluorescein-labelled broad-range $16 \mathrm{~S} \mathrm{rDNA}$ primers and an automatic DNA sequencer (ALF, Pharmacia). DNA sequences were analysed using a DNA managing program (R. Staden, Edinburgh, UK; 4th edition, 1994) and a SunSparc Station 5. Automatic DNA sequencing of the clinical isolates $(\mathrm{HJ} 1-\mathrm{HJ}$ 44) was supplied by the Department of Forensic Serology, University Hospital, Linköping. Partial $16 \mathrm{~S}$ rDNA sequences of the clinical isolates were compared with the DNA sequences of the 19 enterococcal type strains (Devriese et al., 1993; Facklam \& Sahm, 1995) which were assessed by manual DNA sequencing of the BR-PCR-amplified products as described previously (Tiveljung et al., 1995, 1996).

\section{RESULTS}

\section{RAPD analysis of enterococcal clinical isolates}

Band patterns obtained using RAPD analysis on enterococcal crude DNA extracts, including enterococcal isolates $\mathrm{HJ} 1-\mathrm{HJ} 44$ and enterococcal type strains $E$. faecalis ATCC $19433^{\mathrm{T}}$, E. faecium ATCC $19434^{\mathrm{T}}$ and $E$. gallinarum CCUG $18658^{\mathrm{T}}$ are shown in Fig. 1. Several species-specific bands could be observed. The similarity between the strains was evaluated by computerized densitometric analysis of these RAPD profiles as described in Methods. Using UPGMA clustering (Romersburg, 1984), 43 of the 44 isolates were allocated to four different clusters (1-4) at a similarity level of $49 \%$ (Fig. 1 ), arbitrarily chosen for defining species. Cluster 1 contained two enterococcal clinical isolates, two $E$. gallinarum reference strains and E. gallinarum CCUG $18658^{\mathrm{T}}$. In cluster 2 , two enterococcal clinical isolates (HJ 39 and $\mathrm{HJ} 1$ ) clustered together at a similarity level of $52 \%$. Cluster 3 contained E. faecium ATCC $19434^{\mathrm{T}}$, eight enterococcal clinical isolates and five reference strains. Cluster 4 could be divided into subclusters $4 \mathrm{~A}$ and $4 \mathrm{~B}$, merging at a similarity level of $70 \%$. Subcluster $4 A$ contained E. faecalis ATCC $19433^{\mathrm{T}}$ and four reference strains of which one was E. faecalis ATCC $19433^{\mathrm{T}}$, included as a control in the Malmö reference collection (see Methods). Subcluster 4B consisted of 18 enterococcal clinical isolates and E. faecalis ATCC 29212 in duplicate (HJ 9 from the Malmö reference collection and $\mathrm{HJ} 22$ which were included as blind controls among our clinical isolates).

\section{DNA sequence analysis of enterococcal type strains}

In previous studies we were able to show that hybridization probes, derived from variable regions V3, V4 and V9, could be used for the detection and identification of bacterial BR-PCR-amplified products using the universal $16 \mathrm{~S}$ rDNA primers $\mathrm{pJB}-1$ and $\mathrm{p} 13 \mathrm{~B}$ (Monstein et al., 1996; Tiveljung et al., 1995, 1996). BR-PCRamplified products from the 19 enterococcal type strains were subjected to DNA sequence analysis. Based on these partial $16 \mathrm{~S}$ rDNA sequences between positions 1110 and 1180 , and 1240 and 1300 , covering variable regions $\mathrm{V} 4$ and $\mathrm{V} 9$, the 19 enterococcal type strains could be divided into 12 different $16 \mathrm{~S}$ rDNA species groups (Table 1). Variable region V9 (1240-1300) of $E$. faecalis, E. faecium and other enterococci revealed significant DNA sequence differences which allowed the delineation of an E. faecalis-specific sequence ( $5^{\prime}$ GACCGCGAGGTCATGCA 3', 1262-1278; Fig. 2a). The corresponding $E$. faecium sequence, $5^{\prime}$ AGTCGCGAGGCTAAGCT 3', was shared by most other enterococcal type strains (Fig. 2a). However, based on nucleotide sequence differences in variable region V4 derived from the 19 type strains, it was possible to assign a species-specific DNA sequence to E. faecium (Fig. 2b). In E. faecium, nucleotides $C$ and $A$ occurred at positions 1137 and 1154, respectively, of variable region V4, whereas the other Enterococcus type strains had $\mathrm{T}$ and $\mathrm{G}$ or $\mathrm{T}$ and $\mathrm{A}$ at the corresponding positions (Fig. 2b). 


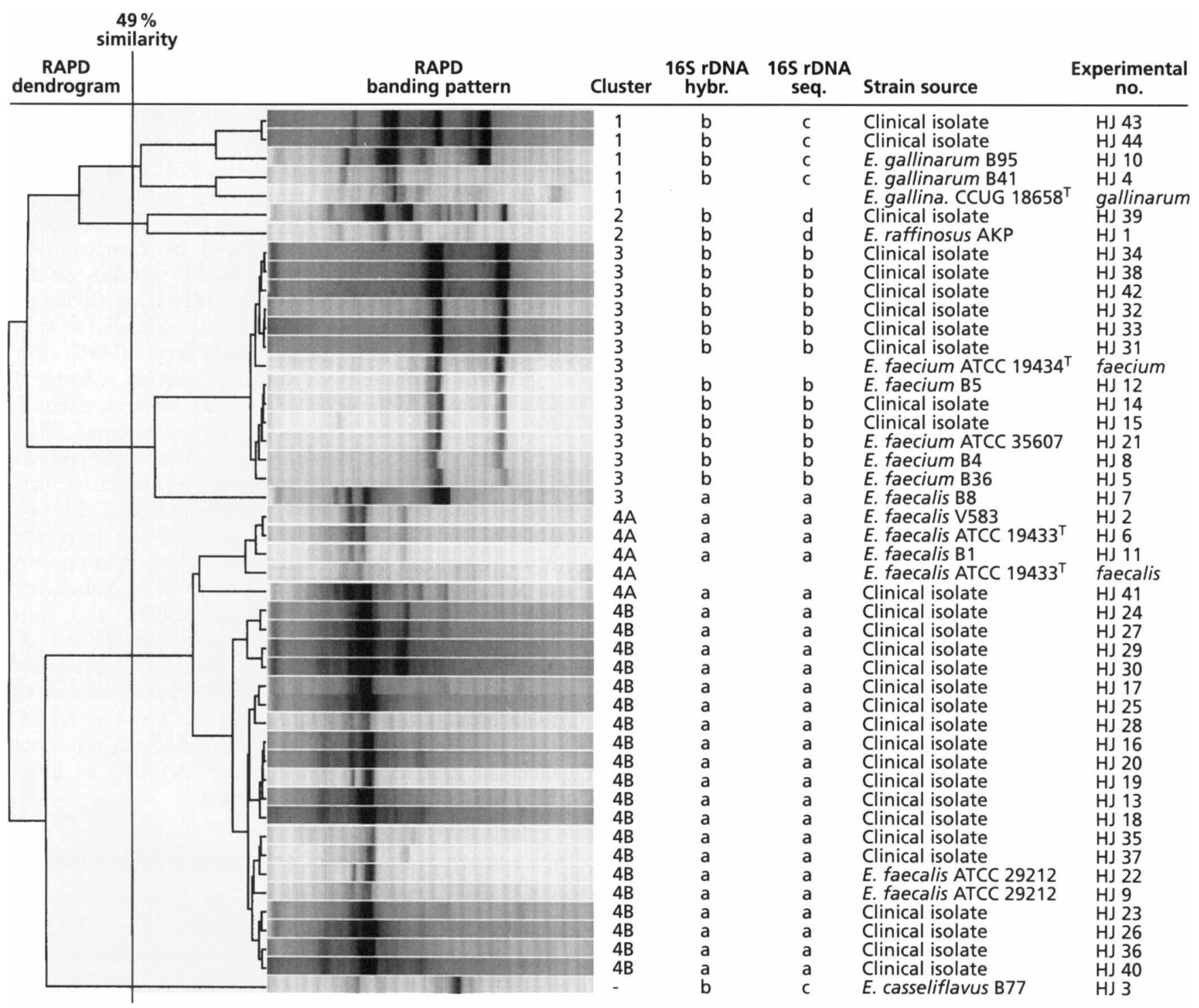

Fig. 1. Dendrogram obtained using RAPD analysis (clusters $1,2,3,4 \mathrm{~A}$ and $4 \mathrm{~B}$ ) and the identification results obtained using 165 rDNA hybridization and partial 165 rDNA sequencing. The hybridization species groups are: $a, E$. faecalis; $b$, other enterococci. The $16 \mathrm{~S}$ rDNA species groups are: a, E. faecalis; $b, E$. faecium; $c$, E. casseliflavus, E. gallinarum, E. flavescens and $E$. dispar; d, E. avium, E. raffinosus and $E$. pseudoavium.

Tabulation of the DNA sequence data in the V4 and V9 regions between positions 1110 and 1180 , and 1240 and 1300 (Fig. 2) allowed further division of the 19 type strains into eight individual species lines and four species groups (Table 1).

\section{BR-PCR amplification and Southern blot analysis of PCR products}

DNA isolated from all enterococcal strains and strains of other genera used in this study was successfully amplified using the universal $16 \mathrm{~S}$ rDNA BR-PCR primers $\mathrm{pJB}-1$ and $\mathrm{p} 13 \mathrm{~B}$, yielding a PCR product of approximately $440 \mathrm{bp}$ as expected. Based on the different DNA sequences, motifs found within variable region V9 in Enterococcus spp., an E. faecalis V9 speciesspecific hybridization probe ( 5 ' GACCGCGAGGTCATGCA $\left.3^{\prime}\right)$ and another hybridization probe (5' AGTCGCGAGGCTAAGCT 3'), representing the corresponding E. faecium sequence (and also most other species of the genus Enterococcus; Fig. 2) were synthesized. Using hybridization conditions as described in Methods, we found that the E. faecalis V9 hybridization probe and the V9 hybridization probe representing other enterococcal species hybridized in a mutually exclusive fashion to the BR-PCR-amplified products of enterococci (Fig. 3), i.e. the E. faecalis probe would not hybridize with DNA from the other enterococci tested, whereas the E. faecium probe hybridized with DNA from all other enterococcal strains in the study except $E$. faecalis. In a parallel experiment, DNA from E. faecalis 
Table 1. Comparison of Enterococcus species group identifications proposed in this study and elsewhere

\begin{tabular}{|c|c|c|c|c|}
\hline \multirow{2}{*}{$\begin{array}{l}\text { Facklam \& Sahm } \\
\qquad(1995)\end{array}$} & \multirow{2}{*}{$\begin{array}{l}\text { Tyrell et al. } \\
\text { (1997) }\end{array}$} & \multirow{2}{*}{$\begin{array}{l}\text { Williams et al. } \\
\quad(1991)\end{array}$} & \multicolumn{2}{|c|}{ This study } \\
\hline & & & Species & $\begin{array}{c}16 \mathrm{~S} \text { rDNA } \\
\text { species group }\end{array}$ \\
\hline $\begin{array}{l}\text { Group I } \\
\text { E. avium } \\
\text { E. malodoratus } \\
\text { E. raffinosus } \\
\text { E. pseudoavium }\end{array}$ & $\begin{array}{l}\text { Group } 1 \\
\text { E. avium } \\
\text { E. malodoratus } \\
\text { E. raffinosus } \\
\text { E. pseudoavium }\end{array}$ & $\begin{array}{l}\text { Avium group } \\
\text { E. avium } \\
\text { E. malodoratus } \\
\text { E. raffinosus } \\
\text { E. pseudoavium }\end{array}$ & $\begin{array}{l}\text { E. avium } \\
\text { E. raffinosus } \\
\text { E. pseudoavium }\end{array}$ & $\begin{array}{l}\mathrm{d} \\
\mathrm{d}\end{array}$ \\
\hline $\begin{array}{l}\text { Group II } \\
\text { E. faecium } \\
\text { E. faecalis } \\
\text { E. mundtii } \\
\text { E. gallinarum } \\
\text { E. casseliflavus } \\
\text { E. flavescens }\end{array}$ & $\begin{array}{l}\text { Group } 2 \\
\text { E. faecium } \\
\text { E. faecalis } \\
\text { E. mundtii } \\
\text { E. gallinarum } \\
\text { E. casseliflavus }\end{array}$ & $\begin{array}{l}\text { Faecium group } \\
\text { E. faecium } \\
\text { E. mundtii } \\
\text { E. durans } \\
\text { E. hirae }\end{array}$ & $\begin{array}{l}\text { E. gallinarum } \\
\text { E. casseliflavus } \\
\text { E. flavescens } \\
\text { E. dispar }\end{array}$ & $\begin{array}{l}\mathrm{c} \\
\mathrm{c} \\
\mathrm{c}\end{array}$ \\
\hline $\begin{array}{l}\text { Group III } \\
\text { E. durans } \\
\text { E. hirae } \\
\text { E. dispar } \\
\text { E. faecalis (var.) }\end{array}$ & $\begin{array}{l}\text { Group } 3 \\
\text { E. durans } \\
\text { E. hirae }\end{array}$ & & E. mundtii & 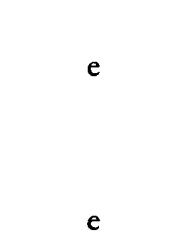 \\
\hline $\begin{array}{l}\text { Group IV } \\
\text { E. sulfureus }\end{array}$ & & & $\begin{array}{l}\text { E. hirae } \\
\text { E. malodoratus }\end{array}$ & $f$ \\
\hline & & $\begin{array}{l}\text { Gallinarum group } \\
\text { E. gallinarum } \\
\text { E. casseliflavus }\end{array}$ & & \\
\hline $\begin{array}{l}\text { Atypical species } \\
\text { E. saccharolyticus } \\
\text { E. cecorum } \\
\text { E. columbae }\end{array}$ & & $\begin{array}{l}\text { Individual species } \\
\text { lines } \\
\text { E. saccharolyticus } \\
\text { E. cecorum } \\
\text { E. columbae } \\
\text { E. faecalis }\end{array}$ & $\begin{array}{l}\text { Individual species } \\
\text { lines } \\
\text { E. saccharolyticus } \\
\text { E. cecorum } \\
\text { E. columbae } \\
\text { E. faecalis } \\
\text { E. faecium } \\
\text { E. sulfureus } \\
\text { E. solitarius } \\
\text { E. seriolicida }\end{array}$ & $\begin{array}{l}\mathrm{g} \\
\mathrm{h} \\
\mathrm{i} \\
\mathrm{a} \\
\mathrm{b} \\
\mathrm{j} \\
\mathrm{k} \\
\mathrm{l}\end{array}$ \\
\hline
\end{tabular}

and E. faecium type strains and from strains of other genera was BR-PCR-amplified and hybridized using enterococcus-specific V9 hybridization probes. As shown in Fig. 4, no cross-hybridization with BR-PCRamplified products from other bacteria included as negative controls was observed. The E. faecium probe also hybridized to Carnobacterium alterfunditum (data not shown) which, however, grows at $16-20^{\circ} \mathrm{C}$ and has no clinical relevance.

\section{DNA sequence analysis of Enterococcus clinical} isolates

Partial 16S rDNA sequences from all enterococcal clinical isolates and reference strains were established by 
(a)

Escherichia coli

S. pyogenes

L. lactis

E. faecalis

E. faecium

E. casseliflavus

E. gallinarum

E. saccharolyticus

E. dispar

E. flavescens

E. sulfureus

E. columbae

E. cecorum

E. avium

E. durans

E. mundtii

E. raffinosus

E. pseudoavium

E. hirae

E. malodoratus

E. solitarius

E. seriolicida

(b)

Escherichia coli

S. pyogenes

L. lactis

E. faecalis
E. faecium
E. casseliflavus
E. gallinarum
E. saccharolyticus
E. dispar
E. flavescens
E. sulfureus
E. columbae
E. cecorum
E. avium
E. durans
E. mundtii
E. raffinosus
E. pseudoavium
E. hirae
E. malodoratus
E. solitarius
E. seriolicida

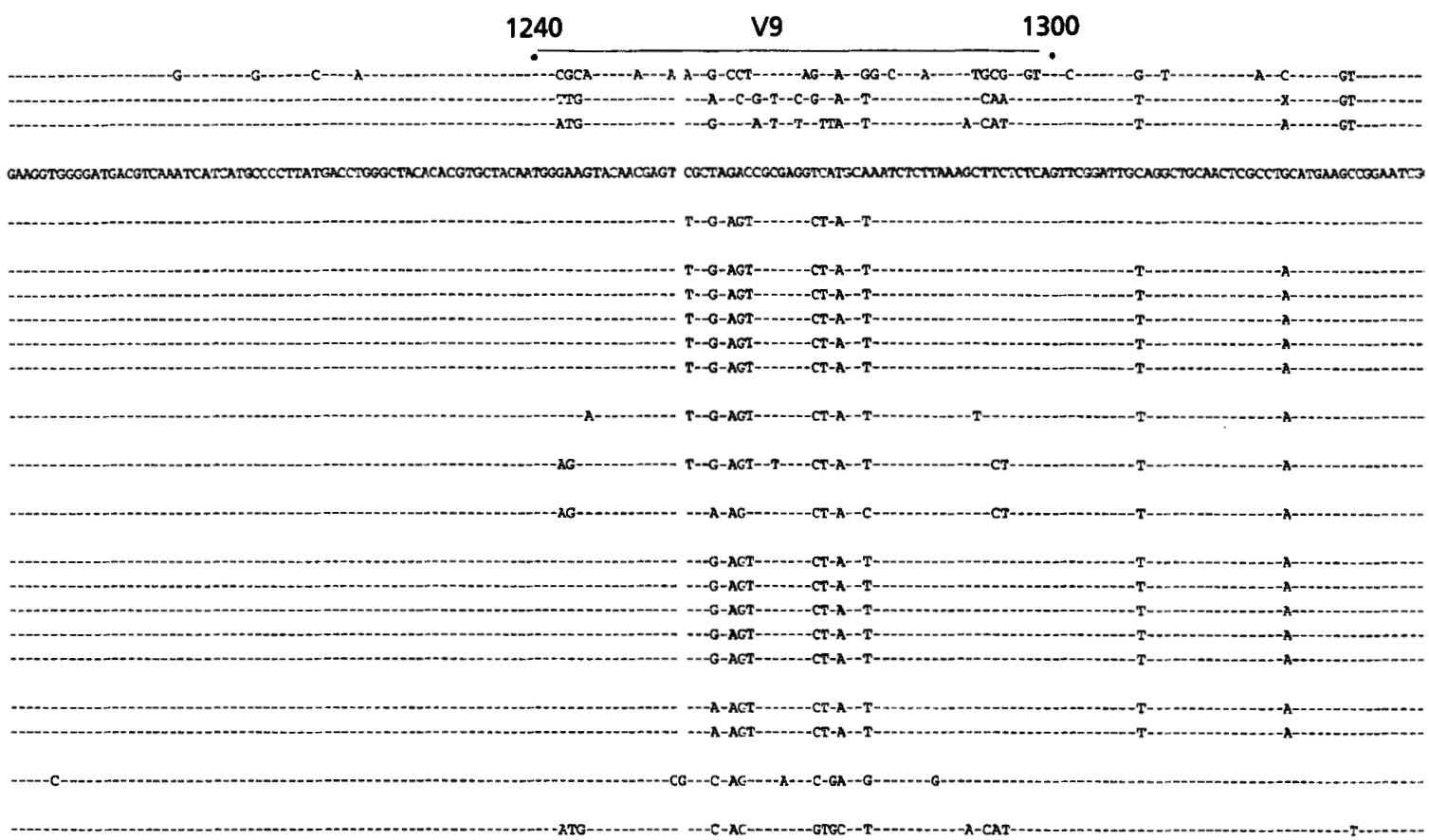

V9 hybridization probe

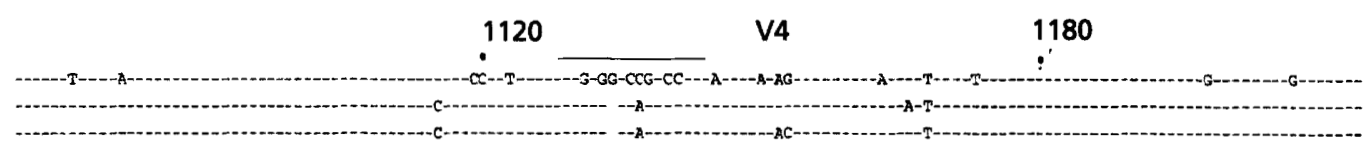

TCGTGTCGTGAGATGTTGGGTTAAGTCCCECAACGAGCGCAACCCTTATTSTTAGTTGCCATCA TTTAGTTGGGCACTETAGCGAGACTGCCGGTGACAAACCGGAGGAAGG:QGGGATGACGTCAMATCATCATGCCCCTTAI

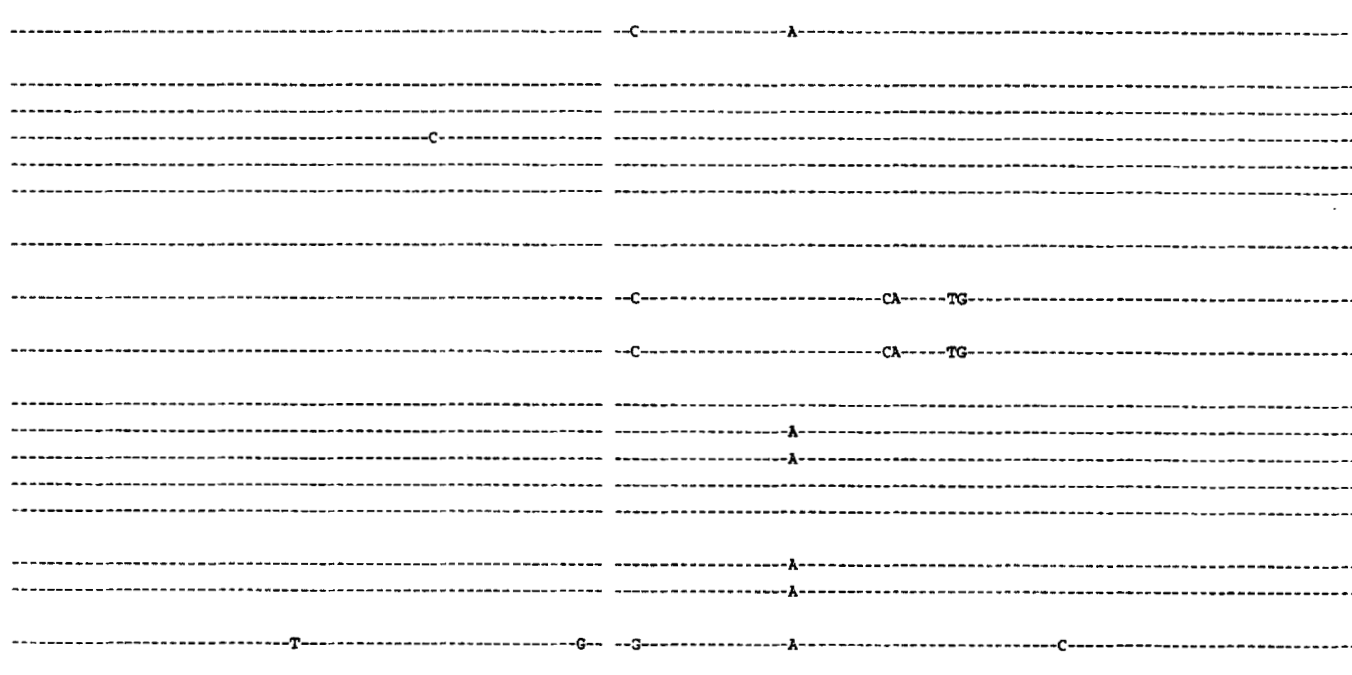

Fig. 2. Alignment of variable regions V9 (a) and V4 (b) of partial 165 rDNA sequences from 19 Enterococcus type strains. Gaps represent base deletions and dashes represent homology to the $E$. faecalis type strain. The location of the $E$. faecalis- and $E$. faecium-specific V9 sequence used as hybridization probe is indicated. Numbering is according to Gray et al. (1984). 16S rDNA sequences were obtained by sequencing BR-PCR-amplified products in our laboratory.

means of automatic DNA sequence analysis of BR-PCRamplified products. Twenty-five clinical isolates showed the E. faecalis-specific V9 sequence motif $5^{\prime}$ CGCT-
AGACCGCGAGGTCATGCA 3' (designated 16S rDNA species group a). Twelve clinical isolates were identified as $E$. faecium (16S rDNA species group b, Fig. 


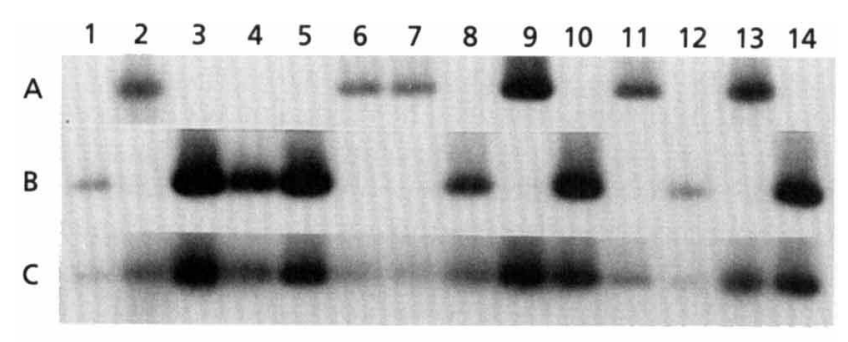

$\begin{array}{llllllllllllll}15 & 16 & 17 & 18 & 19 & 20 & 21 & 22 & 23 & 24 & 25 & 26 & 27 & 28\end{array}$

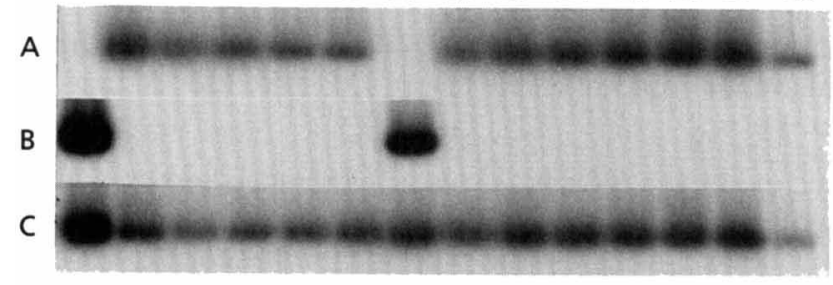

$\begin{array}{llllllllllllll}29 & 30 & 31 & 32 & 33 & 34 & 35 & 36 & 37 & 38 & 39 & 40 & 41 & 42\end{array}$
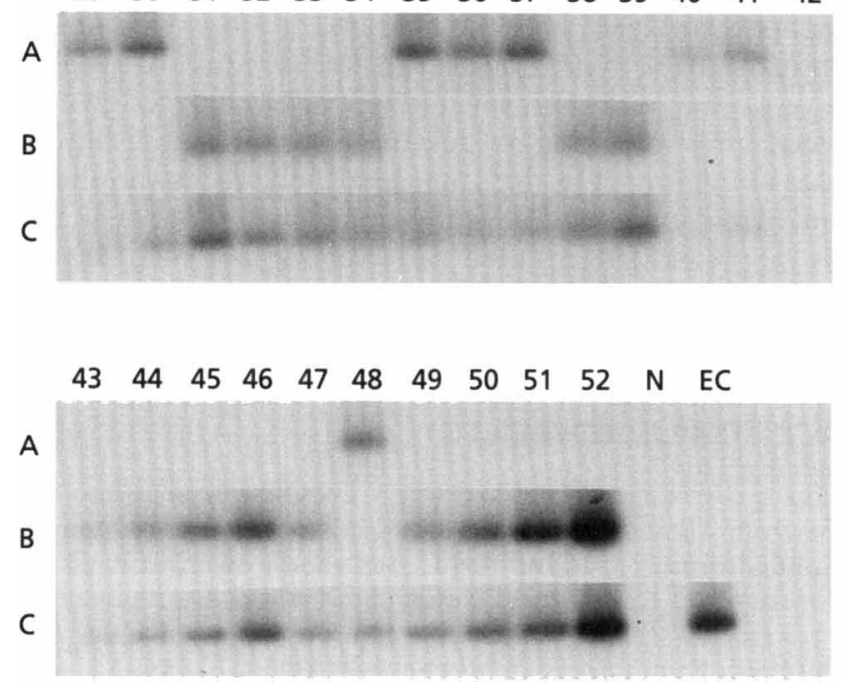

Fig. 3. Southern blot analysis of 165 rDNA BR-PCR products. Membranes were hybridized with a $5^{\prime}$ end-labelled $E$. faecalis V9 antisense probe (A) and a $5^{\prime}$ end-labelled $E$. faecium probe (B). BR-PCR products were visualized by hybridization using the 5' end-labelled bacterial universal BR-PCR primer pJB-1 (C). Membranes were exposed on Amersham MP X-ray film at $-80^{\circ} \mathrm{C}$ using intensifier screens for appropriate times (usually overnight). Lanes: 1-12, strains from the Malmo reference collection; 13-44, clinical isolates from the University Hospital, Linkoping; 45-52, Enterococcus type strains ( $E$. casseliflavus, 45; $E$. durans, 46; $E$. raffinosus, 47; $E$. faecalis, 48; $E$. faecium, 49; $E$. gallinarum, $50 ; E$. hirae, $51 ; E$. mundtii, $52 . \mathrm{N}$, negative control; EC, Escherichia coli.

2). The remaining seven clinical isolates revealed different DNA sequence motifs at positions $1240-1300$ in variable region $\mathrm{V} 9$ (designated $16 \mathrm{~S}$ rDNA species groups $\mathrm{c}$ and $\mathrm{d}$; Figs 1 and 2). In 16S rDNA species group $\mathrm{c}$, the two clinical isolates showed the V9 DNA sequence motif $5^{\prime}$ TGCGAAGTCGCGAGGCTAAGCT $3^{\prime}$ which was present in the type strains representing E. faecium, E. (a)
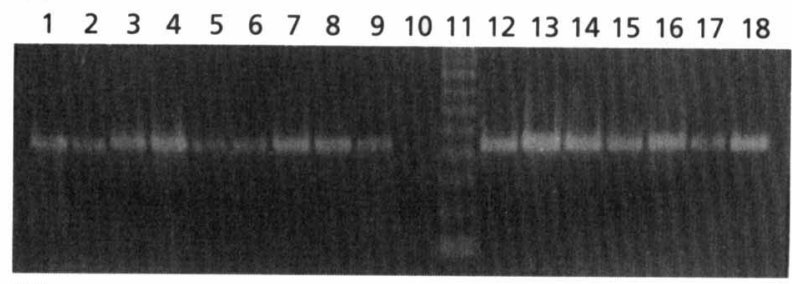

(b)

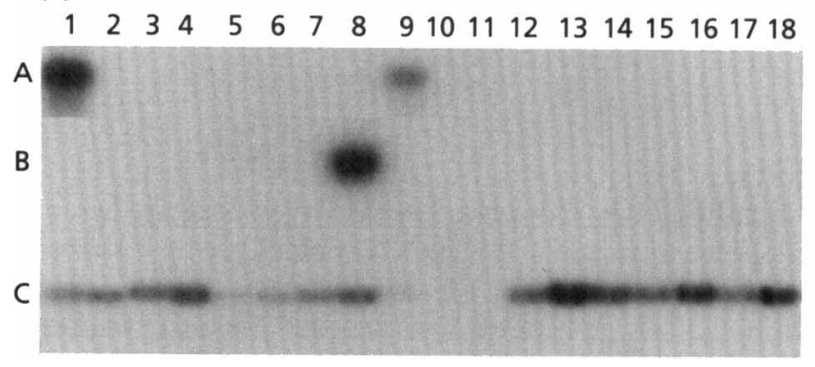

Fig. 4. Ethidium-bromide-stained agarose gel (a) and Southern blot analysis (b) of BR-PCR-amplified products from $E$. faecalis (lanes 1 and 9), Chlamydia trachomatis (2), Helicobacter pylori (3), Mobiluncus sp. (4), Escherichia coli (5), Streptococcus pyogenes (6), Lactococcus lactis (7), E. faecium (8), negative PCR control (PCR mix without DNA template) (10), 100 bp DNA size ladder (Pharmacia) (11), Bordetella pertussis (12), Listeria monocytogenes (13), Staphylococcus aureus (14), Actinomyces sp. (15), Acinetobacter sp. (16), coagulase-negative Staphylococcus sp. (17) and L. lactis (18). Primers used and the exposure of the membranes on X-ray film are as described in the legend to Fig. 3.

casseliflavus, E. gallinarum, E. saccharolyticus, E. dispar and E. flavescens. 16S rDNA species group d (Figs 1 and 2) represents one clinical isolate which had the V9 DNA sequence motif $5^{\prime}$ CGCGAAGTCGCGAGGCTAAGCT 3', present in E. avium, E. durans, E. mundtii, E. raffinosus and E. pseudoavium, (Fig. 2a). Variable region V9-specific DNA sequence motifs corresponding to the remaining enterococcal type strains were not detected among the clinical isolates. Alignment of the partial $16 \mathrm{~S} \mathrm{rDNA}$ sequences of the enterococcal clinical isolates (Fig. 1), revealed complete sequence identity within each $16 \mathrm{~S}$ rDNA species group examined, i.e. $100 \%$ similarity in the sequences with no difference in any base between positions 959 and 1397 (data not shown).

\section{DISCUSSION}

Twenty-four clinical isolates and reference strains were clearly identified as E. faecalis by RAPD analysis comprising cluster 4 (Fig. 1). Based on the partial $16 S$ rDNA sequences, these twenty-four strains, together with an additional strain, $\mathrm{HJ} 7$ which belonged to RAPD cluster 3 (Fig. 1), were designated as 16S rDNA species group a (Fig. 1). RAPD clusters $4 \mathrm{~A}$ and $4 \mathrm{~B}$ and $16 \mathrm{~S}$ rDNA species group a consisting of E. faecalis strains were in good agreement. However, strain $\mathrm{HJ} 7$ ( $E$. faecalis by biotyping and $16 \mathrm{~S}$ rDNA analysis; Fig. 1) clustered together with the E. faecium strain in RAPD 
analysis at a similarity level of $55 \%$. $\mathrm{HJ} 7$ did not show the RAPD pattern expected for E. faecalis (Fig. 1). Instead it revealed an additional band that dominated the RAPD profile. This band is not identical to the band located at a similar position in the E. faecium strains (Fig. 1). Such aberrant dominating bands may arise due to the presence of plasmids carrying antibiotic resistance genes. Indeed, strain HJ 7 (E. faecalis B8, Malmö reference collection) harbours a plasmid-borne van $B$ gene which encodes vancomycin resistance (data not shown). All strains allocated to E. faecium $16 \mathrm{~S}$ rDNA species group b showed the typical $E$. faecium RAPD pattern (Fig. 1). Strains HJ 4, HJ 10 (from the Malmö reference collection) and strains $\mathrm{HJ} 43$ and $\mathrm{HJ} 44$ (clinical isolates from the University Hospital, Linköping), were located in $16 \mathrm{~S}$ rDNA species group c together with E. gallinarum CCUG $18658^{\mathrm{T}}$ in cluster 1 (Fig. 1). Strain HJ 3, which is from the Malmö reference collection and typed as E. casseliflavus B77, was a poor performer in RAPD analysis. In spite of this, the strain had the same partial 16S rDNA sequences as other members of $16 \mathrm{~S}$ rDNA species group c. Similarly, strains $\mathrm{HJ} 39$ and $\mathrm{HJ} 1$ merging together at a similarity level of $52 \%$ and comprising cluster 2 , were representatives of $16 \mathrm{~S}$ rDNA species group d (Fig. 1). It should be noted that only two strains were allocated to cluster 2 by RAPD analysis and no type strain was included. RAPD clustering with only a few representatives may not be significant and, therefore, classification of the rare clinical enterococcal isolate may be simpler and more precise from its $16 \mathrm{~S}$ rDNA sequence covering variable regions V9 and V4. Clearly, RAPD and 16S rDNA sequence analysis are both powerful molecular typing methods for identification of enterococci in clinical isolates. However, due to lack of variation, neither method would seem ideal for subtyping clinical isolates for epidemiological purposes.

Based on phenotypic characteristics (reviewed by Facklam \& Sahm, 1995), or genotypic characteristics such as reverse transcriptase DNA sequence analysis of $16 \mathrm{~S}$ rRNA (Williams et al., 1991) or ITS PCR (Tyrell et al., 1997; Naïmi et al., 1997), various suggestions for the division of the genus Enterococcus into species groups have been put forward (for details see Table 1). It is generally acknowledged that neither biotyping methods (phenotypic characteristics) nor ITS PCR allow simple unequivocal separation of $E$. faecalis, E. faecium and other less frequently encountered enterococcal species (Table 1; Facklam \& Sahm, 1995; Tyrell et al., 1997). The clinical importance of this is obvious since recent studies have revealed that more unusual enterococcal strains such as E. gallinarum, E. casseliflavus, E. durans and E. avium may constitute a significant proportion of clinical isolates (Miele et al., 1995; Perlada et al., 1997; this study). According to our results based on BR-PCRderived partial $16 \mathrm{~S}$ rDNA sequence analysis, the genus Enterococcus may be divided into 12 different $16 \mathrm{~S} \mathrm{rDNA}$ species groups consisting of eight individual species lines (distinct lineages) and four cluster-groups (Fig. 1, Table 1). Admittedly, our division of the genus based on partial $16 \mathrm{~S}$ rDNA sequence information covering variable regions V3, V4 and V9 does not exploit the full potential of this technique. The results of Williams et al. (1991) based on reverse transcriptase sequences suggest that BR-PCR amplification of one or two additional part-sequences in other regions of the $16 \mathrm{~S}$ rRNA genes may provide a complete division of the genus Enterococcus into single species lines. BR-PCR sequencing is a fast method and highly reliable sequences are usually obtained. The $100 \%$ similarity in part-sequences observed within the $16 \mathrm{~S}$ rRNA groups of the clinical isolates included in the present study indicates that automated DNA sequence analysis of part-sequences might be a powerful technique for the typing of enterococci.

In conclusion, we have shown the potential use of RAPD analysis, partial $16 \mathrm{~S}$ rDNA sequence analysis, including variable regions V4 and V9, and Enterococcus-specific $16 \mathrm{~S}$ rDNA hybridization analysis in the identification and classification of enterococci from clinical isolates. As judged from the present data, partial 16S rDNA sequence analysis, including variable regions $\mathrm{V} 4$ and $\mathrm{V} 9$, appears to be a more definitive means of typing enterococci, although several $16 \mathrm{~S}$ rDNA species groups were unresolved due to lack of variation within the V4 and V9 regions. On the other hand, due to its simplicity and slightly higher discriminating power, RAPD analysis might be better suited for studying the relationship between large numbers of strains, for example in the investigation of nosocomial infection epidemiology.

\section{ACKNOWLEDGEMENTS}

This work was supported by the LMÖ-Molecular Biology Program, University Hospital Linköping, the County Medical Council of Östergötland (ÖLL) and the Swedish Council for Forestry and Agricultural Research. The technical assistance of Katarina Ellnebo-Svedlund, Shoreh Nikpour Badr and Elisabeth Palmqvist is greatly acknowledged.

\section{REFERENCES}

Amann, R. I., Ludwig, W. \& Schleifer, K.-H. (1995). Phylogenetic identification and in situ detection of individual microbial cells without cultivation Microbiol Rev 59, 143-169.

Arthur, M. \& Courvalin, P. (1993). Genetics and mechanisms of glyco-peptide resistance in enterococci. Antimicrob Agents Chemother 37, 1563-1571.

Berg, D. E., Akopyants, N. S. \& Kersulyte, D. (1994). Fingerprinting microbial genomes using the RAPD or AP-PCR method. Methods Mol Cell Biol 5, 13-24.

Boyce, J. M., Opal, S. M., Potter-Bynoe, G., LaForge, R. G., Zervos, M. J., Furtado, G., Victor, G. \& Medeiros, A. A. (1992). Emergence and nosocomial transmission of ampicillin resistant enterococci. Antimicrob Agents Chemother 36, 1032-1039.

Center for Disease Control and Prevention (1993). Nosocomial enterococcus resistant to vancomycin, United States 1989-1993. Morb Mortal Wkly Rep 42, 597-599.

Chen, K., Neimark, H., Rumore, P. \& Steinman, Ch. R. (1989). Broad range DNA probes for detecting and amplifying eubacterial nucleic acids. FEMS Microbiol Lett 57, 19-24. 
Devriese, L. A., Pot, B. \& Collins, M. D. (1993). Phenotypic identification of the genus Enterococcus and differentiation of phylogenetically distinct enterococcal species and species groups. $J$ Appl Bacteriol 75, 399-408.

Descheemaeker, P., Lammens, C., Pot, B., Vandamme, P. \& Goossens, H. (1997). Evaluation of arbitrarily primed PCR analysis and pulsed-field gel electrophoresis of large genomic DNA fragments for identification of enterococci important in human medicine. Int J Syst Bacteriol 47, 555-561.

Dutka-Malen, S., Evers, S. \& Courvalin, P. (1995). Detection of glycopeptide resistance genotypes and identification to the species level of clinically relevant enterococci by PCR. J Clin Microbiol 33, 24-27.

Facklam, R. R. \& Sahm, D. F. (1995). Enterococcus. In Manual of Clinical Microbiology, 6th edn, pp. 308-314. Edited by P. R. Murray, E. J. Baron, M. A. Paller, F. C. Tenover \& R. H. Yolken. Washington, DC: American Society for Microbiology.

Goering, R. V. \& Winters, M. A. (1992). Rapid method for epidemiological evaluation of gram positive cocci by field inversion gel electrophoresis. J Clin Microbiol 30, 577-580.

Gray, M. W., Sankoff, D. \& Cedergren, R. J. (1984). On the evolutionary descent of organisms and organelles: a global phylogeny based on a highly conserved structural core in small subunit ribosomal RNA. Nucleic Acids Res 12, 5837-5852.

Hall, L. M. C., Duke, B., Guiney, M. \& Williams, R. (1992). Typing of Enterococcus species by DNA restriction fragment analysis. J Clin Microbiol 30, 915-919.

Issack, M. I., Power, E. G. M. \& French, G. L. (1996). Investigation of an outbreak of vancomycin-resistant Enterococcus faecium by random amplified polymorphic DNA (RAPD) assay. $J$ Hosp Infect 33, 191-200.

Kostman, J. R., Mitchell, B. A., Mair, M., Edlind, T. D., LiPuma, J. J. \& Stull, T. L. (1995). A universal approach to bacterial molecular epidemiology by polymerase chain reaction ribotyping. J Infect Dis 171, 204-208.

Landman, D., Mobaraki, N. K. \& Quale, J. M. (1993). Novel antibiotic regimens against Enterococcus faecium resistant to ampicillin, vancomycin, and gentamicin. Antimicrob Agents Chemother 37, 1904-1908.

Miele, A., Bandera, M. \& Goldstein, B. P. (1995). Use of primers selective for vancomycin resistance genes to determine van genotype in enterococci and to study gene organization in VanA isolates. Antimicrob Agents Chemother 39, 1772-1778.

Moellering, R. C. (1995). Enterococcus species, Streptococcus bovis, and Leuconostoc species. In Principles and Practice of Infectious Diseases, 4th edn, pp. 1826-1835. Edited by G. L. Mandell, J. E. Bennett \& R. Dolin. New York: Churchill Livingstone.

Monstein, H.-J., Kihlström, E. \& Tiveljung, A. (1996). Detection and identification of bacteria using in-house broad range $16 \mathrm{~S}$ rDNA PCR amplification and genus-specific DNA hybridization probes, located within variable regions of $16 \mathrm{~S}$ rRNA genes. APMIS 104, 451-458.

Murray, B. E., Singh, K. V., Heath, J. D., Skharma, B. R. \& Weinstock, G. M. (1990). Comparison of genomic DNAs of different enterococcal isolates using restriction endonucleases with infrequent recognition sites. J Clin Microbiol 28, 2059-2063.
Naîmi, A., Beck, G. \& Branlant, C. (1997). Primary and secondary structures of rRNA spacer regions in enterococci. Microbiology $143,823-834$.

Noble, W. G., Virani, Z. \& Cree, R. G. A. (1992). Co-transfer of vancomycin and other resistance genes from Enterococcus faecalis NCTC 12201 to Staphylococcus aureus. FEMS Microbiol Lett 93, 195-198.

Perlada, D. E., Smulian, A. G. \& Cushion, M. T. (1997). Molecular epidemiology and antibiotic susceptibility of enterococci in Cincinnati: a prospective citywide survey. J Clin Microbiol 35, 2342-2347.

Power, E. G. M. (1996). RAPD typing in microbiology, a technical review. J Hosp Infect 34, 247-265.

Poyart, C., Pierre, C., Quesne, G., Pron, B., Berche, P. \& Trieu-Cuot, P. (1997). Emergence of vancomycin resistance in the genus Streptococcus: characterisation of a $v a n B$ transferable determinant in Streptococcus bovis. Antimicrob Agents Chemother 41, 24-29.

Relman, D. A., Schmidt, T. M., MacDermott, R. P. \& Falkow, S. (1992). Identification of uncultured bacillus of Whipple's disease. $N$ Engl J Med 327, 293-301.

Romersburg, H. C. (1984). Cluster Analysis for Research. Belmont, CA: Lifetime Learning Publications.

Schleifer, K. H. \& Kilpper-Bälz, R. (1984). Transfer of Streptococcus faecalis and Streptococcus faecium to the genus Enterococcus nom. rev. as Enterococcus faecalis comb. nov. and Enterococcus faecium comb. nov. Int J Syst Bacteriol 34, 31-34.

Schleifer, K. H. \& Kilpper-Balz, R. (1987). Molecular and chemotaxonomic approaches to the classification of streptococci, enterococci and lactococci: a review. Syst Appl Microbiol 10, 1-19.

Stahl, D. A. \& Amann, R. (1991). Development and application of nucleic acid probes. In Nucleic Acid Techniques in Bacterial Systematics, pp. 205-212. Edited by E. Stackebrandt \& M. Goodfellow. Chichester: Wiley.

Tiveljung, A., Backström, J., Forsum, U. \& Monstein, H.-J. (1995). Broad-range PCR amplification and DNA sequence analysis reveals variable motifs in $16 \mathrm{~S}$ rRNA genes of Mobiluncus species. APMIS 103, 755-763.

Tiveljung, A., Forsum, U. \& Monstein, H.-J. (1996). Classification of genus Mobiluncus based on comparative partial 16S rRNA gene analysis. Int J Syst Bacteriol 46, 332-336.

Tyrell, G. J., Bethune, R. N., Willey, B. \& Low, D. E. (1997). Species identification of enterococci via intergenic ribosomal PCR. J Clin Microbiol 35, 1054-1060.

Williams, A. M., Rodrigues, U. M. \& Collins, M. D. (1991). Intrageneric relationships of enterococci as determined by reverse sequencing of small subunit rRNA. Res Microbiol 142, 67-74.

Woodford, N., Morrison, D., Johnson, A. P., Briant, V., Georg, R. C. \& Cookson, B. (1993). Application of DNA probes for rRNA and $v a n A$ genes to investigation of a nosocomial cluster of vancomycin-resistant enterococci. J Clin Microbiol 31, 653-658.

Received 1 October 1997; revised 21 January 1998; accepted 30 January 1998. 